\title{
The Moslem World
}

$\begin{array}{lll}\text { VoL. VI APRIL, } 1916 & \text { No. } 2\end{array}$

\section{EDITORIAL}

—:0:-

RARELY, if ever, since the destruction of Jerusalem by Titus, have such scenes been witnessed on the face of the earth as those which have recently occurred, and are still taking place, in the slaughter of the helpless Armenians in the Turkish Empire. The resemblance between the history and the age-long sufferings of the Jews and those of the Armenians is very striking, whatever the reason for it may be. But the Romans, when they slaughtered the people of Jerusalem, had an excuse which the Turks have not in their attempt to destroy the Armenians. The Jews had rebelled and were fighting bravely for their freedom. Moreover, intestine struggles within the ranks of the Jews themselves were responsible for not a little of the bloodshed. It is quite otherwise in the present case. The Armenians are not in rebellion. They are quite helpless and defenceless, not being allowed by Turkish law to carry arms. Living either in separate unwalled villages or among their Turkish fellow-subjects (who a few years ago welcomed them to share in the newly-proclaimed "Liberty, Fraternity, Equality "), with scarcely an exception, they could offer no resistance, if they would. They, like their Master and ours, are led as sheep to the slaughter. For no crime, real or supposed, without even the pretence of a trial, men, women and children to the number of 800,000 , have been torn from their homes, hurried into the interior of Asia Minor, and there mercilessly destroyed by cold, hunger, ill-treatment, cut to pieces, massacred in a hundred ways, amid scenes of horror

NOTE.-Readers of this Review are reminded that the publishers do not necessarily endorse the particular views expressed in the several articles or on any of the pages of the Revlew. 
which cannot be adequately described. Martyrs they are, for their one offence was their faith in Christ.

There are those who maintain that Muhammadanism has nothing to do with this awful crime. True it is that to massacre the Christian Dhimmîs of an Islâmic state is not in accordance with the letter of the law of the Qur'ân, but it is none the less true that Islamic fanaticism is the cause of such deeds now, just as it has ever been since the Hijrah of the "Prophet with the sword." It is only to Jews and Christians who are not yet in subjection to Muslim authority that reference is made in the text: "Fight ye against those who believe not in God nor in the Last Day, nor forbid what God and His Apostle have forbidden, nor profess the true religion, from among those who have been brought the Book" (i.e., the Bible), " until they give the tribute (jizyah) out of hand and be brought low" (Surah ix. 29); yet it has always been difficult for earnest Muslims to see why they should not show their zeal for the Faith by wielding the sword against those among them who would not accept Muhammad's claims. Hence the unceasing oppression to which Christians in all Islâmic countries have ever been subject, oppression varied only by massacre.

As Professor Margoliouth says: "It is a marvel to all who have considered Eastern Christianity and its circumstances since the Islâmic conquests, that it should have survived at all " (cf., "Hibbert Lectures," 1913, p. 134). The Adana Massacre of a few years back was only one of many such. Nor have the Armenians been the only Christians whose existence has been for ages one of terror and degradation unspeakable. Yet this Martyrnation has had a harder lot perhaps than any other.

There may be doubt whether (as Armenian tradition, recorded by Moses of Khorênê, states) their king Abgar was baptised by Thaddeus, one of our Lord's seventy disciples, not long after the Ascension; but there is none that Armenians under King Tiridates (baptised by the Apostle of Armenia, Gregory the Illuminator in A.D. 302) were the first nation to accept Christianity as the national religion. Their version of the Bible, published in A.D. 436, is deservedly called the Queen of Versions. 
While its language was still the vernacular of the people, Armenian missionaries went forth boldly to preach the Gospel in Georgia, Albania, Persia and other lands. The Bible long remained the national book of the Armenians. It has coloured the whole mass of their ancient literature. To its sacred teaching they clung throughout all the fierce persecutions inflicted upon them by the Persian monarchs whenever the fortune of war gave them for a time the upper hand. The early martyrs of the Armenian Church are rivalled by many, excelled by none. Their devotion to the Word of God has been the cause of their retention of their nationality during all the centuries of affliction which have followed the Muhammadan conquest. Age after age have they resisted unto death every attempt by force or fraud to induce them to forsake Christ crucified. Their existence has been a misery ; they have lost freedom, property, all that makes life dear to men; yet, even when lapse of years has changed their ancient tongue so much as to make their service books unintelligible to the mass of the people, they have still clung to their faith, and now a last attempt is being made to quench that faith in their blood.

We cannot believe that this attempt will be permitted to succeed. Like the Jews in their age-long sufferings, these people have been preserved for a Divine purpose. Doubtless when the days of misery are past they will arise in new spiritual life and zeal, drawn nearer to Christ by the fires of persecution, in which "One like unto the Son of Man" has walked with them, loving Him yet more for all they have undergone for His Name's sake, and as ready as were their forefathers to preach the Gospel to the children of their persecutors, that they may see the light of life.

Our sympathy goes out to our Armenian brethren; and many, both in England and America, are even now striving to aid the destitute whose lives have been spared. Let us help them with our prayers, too, that they may stand fast in the faith, and that in Armenia in the future as in the past it may be seen that the blood of the martyrs is the seed of the Church.

W. St. Clatr Tisdall. 